\title{
The Impact of Teamwork on Organizational Performance: A Case Study of First City Monument Bank Lagos, Nigeria
}

\author{
Oludare Ayodeji AFOLAMI \\ Istanbul Aydin University, Institute of Graduate Studies, Turkey
}

\begin{abstract}
The study investigated the impact of teamwork on organization performance using First City Monument Bank as a case study. This study has been examined by previous scholars and further investigation is still ongoing in this area. However, this study gathered information using primary survey where questionnaire was distributed to the employees of the First City Monument Bank and used descriptive statistic, factor analysis, correlation test and regression analysis. The findings showed that teamwork cohesion is positive and significant to impact on organizational performance and concluded that the performance of organization is a subset of operating performance while teamwork is a subset of unit performance and teamwork cohesion gives employees a sense of possession and promotes cooperation.
\end{abstract}

Keywords: Teamwork, Incentives, Operating Performance, and Organization Performance

DOI: $10.7176 /$ RJFA/11-14-05

Publication date:July $31^{\text {st }} 2020$

\section{Introduction}

Teamwork is a means of working together towards a set goal providing the necessary synergy where people get empowered in the working relationship to achieve continuous performance improvement and a better understanding of the importance of collective action towards career advancement (Adeleke, 2008). Properly developed teamwork relations enhance multiple skills on the individual members where there is creative problemsolving skills and easy learning when new concepts are being introduced. At an effective teamwork level, learning becomes easier in comparison to the absence of teamwork and individual performance is improved with the enhanced learning (Howard, Turban \& Hurley, 2016). Teamwork can be tolerated as one of the factors of survival and a top priority of any organization, and there can be many organizations that have utilized teamwork in some sense to attain market efficiency. It is common to pay attention to service team, manufacture team, management team, or the whole firm, indicating as team which a lot of firms nowadays are moving to 'team based' activity advancement, this implies that effectiveness in team is a vital way to know whole lot of task carried out in a firm. Therefore, managers/owners know the value of workers as a team and encouraging with the capability to work in that manner (Richard, 1991).

Thus, with augmented competition everywhere, which makes managers/leaders at the present, acknowledged the significance of teamwork more than ever before. In this sense, individuals' production can be increased by the teams through the effort of the group. To improve manpower utilization and to raise the performance of individuals it is essential for employees to work in a team in any organization. These features in an organization have a far above the ground important role to play. Every organization have more than a few persons to carry out activities and every framework of organization variable calculates the range in which an organization offers support or resources to a team, for the team to thrive (Doolen, Hacker \& Aken, 2006). Nonetheless, Poor productivity of teamwork has had an influence on the whole output of employee's efficiency of any firm. This have, as a result, created interactive and comportment character against the manager that prompted lesser team courage, disappointment and even doubt now and again, subsequently low generation at work put this investigation search to appraise the effect of teamwork on organizational productivity using a case of First City Monument Bank, Lagos. It also assessed how to achieve greater productivity with business teamwork strategies, examine the teamwork essentiality in organization's productivity and to deduce on how teamwork can augment organizational productivity. Since no firm can operate alone without a strong team hence, this study makes deductions on how teamwork can enhance organizational productivity.

\section{Literature Review}

\subsection{Teamwork and Organization}

Teamwork organization, activities and events usually define the relationship of the employee with the department under which they operate (Wanyeki, maina, Sanyanda \& Kiiru, 2019). It follows that work floors being the units of operations, they contribute significantly to the personal image of the employees serving in those departments and shapes their perspective and commitment towards the course of the organization. Poor team organization, evaluation, reward system, and leadership will often bring about low morale and negative motivation towards individual performance. The employees usually take their activities sluggishly towards accomplishing basic actions and generally nothing important gets done (Husain, 2011). Organization occurs when people collaborate 
with one another to reach the desired intended outcome or target. It could also occur through deliberately planned action, accidental improvising, or some mixture of the two, but it always relies on cooperative effort. The organization is a mechanism that integrates the work that groups or individuals will carry out with the resources required to carry out the work, so that the activities conducted provide the best outlets for the effective, organized, productive and structured execution of the effort possible.

\subsection{Empirical Review}

Wanyeki, Maina, Sanyanda and Kiiru (2019) wrote on the influence of teamwork on worker performance in Kenyatta University. Interview and questionnaire were used as the method of data collection from the purposive respondent in the study. It was found that teamwork has proven to be closely related to the performance of the individual employee. Sanyal and Hisam (2018) investigated teamwork impact on work performance of faculty members in Dhofar university. Primary source of data was employed for analytical purpose. This study revealed that there is a significant association between teamwork, climate of trust, leadership and structure, rewards, and the performance of the faculty members during the study period in Oman at Dhofar university. Khan and AlMashikhi (2017) evaluated teamwork on employee performance in the financial sector particularly banking where the study collected data from 120 employees using correlation method and regression test. The study revealed that positive and direct connection exists between teamwork and employees' performance and it was further showed that there exists a significant impact of teamwork on employee performance.

Salman and Hassan (2016) studied teamwork and its effect on employee performance applying descriptive and exploratory design in Malaysia. 107 subjects were used from the population of the selected entertainment company. It was indicated that all the selected features exhibited significant associations with teamwork. Mores so, some independent variables such as efficient communication, level of trust, leadership and accountability revealed a positive and significant influence on employee performance. Agarwal \& Adjirackor's (2016) empirically studied teamwork impact on organizational productivity in Ghana. The general results of Agarwal \& Adjirackor (2016) show that teamwork results in benefits such as increased productivity, improved organizational performance, competitive edge and enhanced product quality and quantity greatly contributes to productivity in organizations in comparison to other factors. The authors argued that employers could enhance their organizations' performances through increasing the level of teamwork and making efforts to increase individuals' performance levels, but to be successful, they need to consider the quantity and kind of teamwork provided.

Agwu (2015) investigated the linking between teamwork and employee performance in Nigeria. He employed descriptive research design where questionnaire distribution was randomly used to gather the data. The findings showed that there exists significant connection between teamwork and employee performance. Boakye (2015) examined the influence teamwork has on employee performance in Ghana using convenience and purposive form of sample techniques. The correlation analysis affirmed that teamwork and other measures variable are positively related with organization performance during the study period. Ooko \& Odundo (2015) assert that effective teamwork positively influences organizational performance. Organizations throughout the world are working very hard to enhance their teams' effectiveness to gain global competitiveness. Presently, many organizations have employed teamwork as an important element that helps achieve success. Mbinya (2013) asserts that most organizations have adopted teamwork to accomplish their performance targets.

Frobel and Marchington (2005) investigated teamworking structures and worker discernments in British and Germany Multinational Companies. Interview was conducted, and questionnaire were used and distributed to pharmaceutical firms' employees. The study findings revealed that despite the major differences at the two national levels and structure, team member perceptions are surprisingly similar at the two sites. A study by Fedor, Ghosh, Caldwell \& Singhal (2003) shows that there are numerous features showing effectiveness of teams such as team leadership, the importance of such margins comprises those between a team member and team leaders (Stock, 2006). Both teamwork level between team leaders and team members with the sort of activities used by teams to realize their purposes, while, (Pearson \& Ensley, 2005) claims that business achievement depends on dexterity with other teams and synergy in the top management. These factors are vital to team unity and group strength which finally lead to organizational effectiveness. Therefore, this study centers on the issues that are leadership support, inter-team relationship, collaborative management, and team unity and group strength outcome on organizational effectiveness. 
Table 1: Review Summary

\begin{tabular}{|c|c|c|c|}
\hline Author Name \& Year & Nation & Heading & Findings \\
\hline $\begin{array}{l}\text { Wanyeki, } \begin{array}{r}\text { Maina, } \\
\text { Sanyanda and Kiiru } \\
(2019)\end{array}\end{array}$ & Kenya & $\begin{array}{l}\text { The impact of teamwork on } \\
\text { employee performance in } \\
\text { Kenyatta University. }\end{array}$ & $\begin{array}{l}\text { It was found that teamwork has } \\
\text { proven to be closely related to the } \\
\text { performance of the individual } \\
\text { employee. }\end{array}$ \\
\hline $\begin{array}{l}\text { Sanyal and Hisam } \\
(2018)\end{array}$ & Oman & $\begin{array}{lcr}\text { Teamwork on } & \text { work } \\
\text { performance } & \text { of } & \text { faculty } \\
\text { members in Dhofar university. }\end{array}$ & $\begin{array}{l}\text { This study revealed that there is a } \\
\text { strong and significant association } \\
\text { between the dependent and } \\
\text { independent variables. }\end{array}$ \\
\hline $\begin{array}{l}\text { Khan and Al-Mashikhi } \\
(2017)\end{array}$ & & $\begin{array}{l}\text { Teamwork on employee } \\
\text { performance in the financial } \\
\text { sector particularly banking }\end{array}$ & $\begin{array}{l}\text { The study revealed that positive and } \\
\text { direct connection exist between } \\
\text { teamwork and employees' } \\
\text { performance }\end{array}$ \\
\hline $\begin{array}{l}\text { Salman and Hassan } \\
(2016)\end{array}$ & Malaysia & $\begin{array}{l}\text { Teamwork and its effect on } \\
\text { employee performance. }\end{array}$ & $\begin{array}{l}\text { This study found that all the selected } \\
\text { features have significant associations } \\
\text { with teamwork. }\end{array}$ \\
\hline $\begin{array}{l}\text { Agarwal \& Adjirackor } \\
(2016)\end{array}$ & Ghana & $\begin{array}{l}\text { Teamwork impact on } \\
\text { organizational productivity in } \\
\text { Ghana. }\end{array}$ & $\begin{array}{l}\text { There exists positive significant } \\
\text { impact of the explanatory on the } \\
\text { control variable }\end{array}$ \\
\hline$(2015)$ & Nigeria & $\begin{array}{l}\text { Teamwork and employee } \\
\text { performance in Nigeria. }\end{array}$ & $\begin{array}{l}\text { The findings showed that there exists } \\
\text { significant relationship between } \\
\text { teamwork and } \\
\text { performance. }\end{array}$ \\
\hline Boakye (2015) & Ghana & $\begin{array}{l}\text { Teamwork has on employee } \\
\text { performance in Ghana }\end{array}$ & $\begin{array}{l}\text { Teamwork and other measures } \\
\text { variable are positively related with } \\
\text { organization performance during the } \\
\text { study period. }\end{array}$ \\
\hline $\begin{array}{l}\text { Frobel and Marchington } \\
(2005)\end{array}$ & $\begin{array}{l}\text { British } \\
\text { and } \\
\text { Germany }\end{array}$ & $\begin{array}{l}\text { Teamworking structures and } \\
\text { worker perceptions in British } \\
\text { and Germany Multinational } \\
\text { Companies. }\end{array}$ & $\begin{array}{l}\text { Despite the major differences at the } \\
\text { two national levels and structure, } \\
\text { team member perceptions are still } \\
\text { similar. }\end{array}$ \\
\hline
\end{tabular}

Source: Writer's computation (2020)

\section{Study Method}

The population was focused on the employees of the First City Monument Bank (FCMB), Lagos. FCMB Limited is a member of FCMB Group Plc, which is among the top financial institutions in Nigeria. The study sample consists of some selected employees of FCMB within Lagos. Multistage sampling technique was employed where 150 employees were targeted for the survey. The first stage includes the selection of thirty (30) branches of FCMB randomly from different areas in Lagos. Secondly, five employees were selected from each branch and finally, one hundred and fifty (150) respondents were random targeted from the selected branches of FCMB.

The instrument utilized for the gathering of information was self-developed survey using five Likert scale, such as strongly agree, agree, undecided, strongly disagree, and disagree. This survey was categorized into two segments. Section A comprises of the statistic attributes of the participants while section B contains information on participants' perspectives on impact of teamwork on organizational performance. 


\section{Discussion of Findings}

4.1 Demographic Analysis

Table 2: Demographic Report

\begin{tabular}{|l|r|r|}
\hline & Frequency & Percentage \\
\hline Gender & 62 & 51.2 \\
\hline Male & 59 & 48.8 \\
\hline Female & 5 & 4.1 \\
\hline Marital Status & 116 & 95.9 \\
\hline Single & & \\
\hline Married & 2 & 1.7 \\
\hline Age & 65 & 53.7 \\
\hline $18-29 y r s$ & 32 & 26.4 \\
\hline $30-39 y r s$ & 22 & 18.2 \\
\hline $40-49 y r s$ & & \\
\hline Above 50yrs & 103 & 85.1 \\
\hline Academic Level & 4 & 3.3 \\
\hline OND & 2 & 1.7 \\
\hline HND/BSc & 12 & 9.9 \\
\hline MSc/MBA & 121 & \\
\hline Ph.D. & & \\
\hline Total Respondents & & \\
\hline Source: Writs & & \\
\hline
\end{tabular}

Source: Writer's compilation (2020)

The demographic report reveals that 59 of the participants with $48.8 \%$ are female while the 62 participants with $51.2 \%$ are male. 5 respondents with $4.1 \%$ are single according to the participants marital status while 116 respondents representing $95.9 \%$ are married. 2 respondents with $1.7 \%$ are between the age group of 18-29years, 65 respondents with $53.7 \%$ are between 30-39year group, 32(26.4\%) are between age group of 40-49years while 22 respondents with $18.2 \%$ are above 50years of age. 103 respondents representing $85.1 \%$ are OND holders, 4 respondents with 3.3\% are HND/BSC holders, 2(1.7\%) are MSC/MBA holders while 12 respondents with $9.9 \%$ are Ph.D. holders. 19 respondents indicating $15.7 \%$ are than less than 5years in working for the organization, 23 respondents with $19.0 \%$ are between 5-8years, 51 respondents with $42.1 \%$ are between $9-12$ years, 9 respondents indicating $7.4 \%$ are between $13-16$ years while 19 respondents with $15.7 \%$ are 17 years and above.

\subsection{Factor Analysis}

Table 3: Total Variance Explained

\begin{tabular}{|l|c|c|c|c|c|c|}
\hline \multirow{2}{*}{ Component } & \multicolumn{4}{|l|}{ Initial Eigenvalues } & \multicolumn{3}{|l|}{ Extraction Sums of Squared Loadings } \\
\cline { 2 - 7 } & Total & \% of Variance & Cumulative \% & Total & \% of Variance & Cumulative \% \\
\hline 1 & 7.547 & 68.606 & 68.606 & 7.547 & 68.606 & 68.606 \\
\hline 2 & 1.048 & 9.531 & 78.137 & 1.048 & 9.531 & 78.137 \\
\hline 3 & .555 & 5.042 & 83.179 & & & \\
\hline 4 & .500 & 4.547 & 87.726 & & & \\
\hline 6 & .354 & 3.218 & 90.944 & & & \\
\hline 7 & .258 & 2.346 & 93.290 & & & \\
\hline 8 & .213 & 1.937 & 95.227 & & & \\
\hline 9 & .195 & 1.774 & 97.001 & & & \\
\hline 10 & .143 & 1.304 & 98.305 & & & \\
\hline 11 & .105 & .956 & 99.260 & & & \\
\hline
\end{tabular}

Source: Writer's compilation (2020)

Table 3 displays the variance explained by the component of the questionnaire. From the extraction sums of squared loading of the cumulative, the first two components values are 68.606 and 78.137 respectively. This means that the second component has revealed a variation of $78 \%$ in the data.

\subsection{Descriptive Analysis}

At first, to understand the central tendency and dispersion of the data, descriptive statistics are investigated. All variables are in a Likert scale; that's why maximum and minimum values are 1 and 5. 
Table 4: Descriptive Statistics

\begin{tabular}{|l|l|l|l|l|l|l|l|l|l|}
\hline & $\mathrm{N}$ & Minimum & Maximum & Mean & $\begin{array}{l}\text { Std. } \\
\text { Deviation }\end{array}$ & Skewness & $\begin{array}{l}\text { Std. } \\
\text { Error }\end{array}$ & Kurtosis & $\begin{array}{l}\text { Std. } \\
\text { Error }\end{array}$ \\
\hline $\begin{array}{l}\text { Organizational } \\
\text { Performance }\end{array}$ & 121 & 1 & 5 & 1.83 & 1.247 & 1.393 & .220 & .739 & .437 \\
\hline $\begin{array}{l}\text { Teamwork } \\
\text { Cohesion }\end{array}$ & 121 & 1 & 5 & 2.10 & 1.158 & .918 & .220 & .035 & .437 \\
\hline Group Potency & 121 & 1 & 5 & 1.98 & 1.060 & .988 & .220 & .113 & .437 \\
\hline $\begin{array}{l}\text { Persistent } \\
\text { Communication }\end{array}$ & 121 & 1 & 5 & 1.97 & 1.147 & -.975 & .220 & .040 & .437 \\
\hline Incentives & 121 & 1 & 5 & 1.75 & 1.149 & 1.505 & .220 & 1.332 & .437 \\
\hline Valid N (listwise) & 121 & & & & & & & & \\
\hline
\end{tabular}

Source: Writer's compilation (2020)

The descriptive analysis of the variables shows that minimum, maximum, mean, standard deviation, skewness and kurtosis statistics. The reports reveal that the average value of organizational performance is 1.83 , teamwork cohesion is 2.10 , group potency is 1.98 , persistent communication is 1.97 and incentives is 1.75 . The standard deviation values were also presented and are smaller in unit. More so, the skewness statistic shows that all the variables are positively skewed except persistent communication which is negatively skewed. The Kurtosis statistic reveals that all the proxies are thin tailed in nature that is they are smaller in value (not more than 3 ).

\subsection{Correlation Analysis}

Table 5: Correlations

\begin{tabular}{|c|c|c|c|c|c|c|}
\hline & & $\begin{array}{l}\text { Organizational } \\
\text { Performance }\end{array}$ & \begin{tabular}{|l|} 
Teamwork \\
Cohesion
\end{tabular} & \begin{tabular}{|l} 
Group \\
Potency
\end{tabular} & $\begin{array}{l}\text { Persistent } \\
\text { Communication }\end{array}$ & Incentives \\
\hline \multirow{3}{*}{$\begin{array}{l}\text { Organizational } \\
\text { Performance }\end{array}$} & \begin{tabular}{|l} 
Pearson \\
Correlation
\end{tabular} & 1 & $.716^{* *}$ & -.079 & $.707^{* *}$ & $.738^{* *}$ \\
\hline & Sig. (2-tailed) & & .000 & .391 & .000 & .000 \\
\hline & $\mathrm{N}$ & 121 & 121 & 121 & 121 & 121 \\
\hline \multirow{3}{*}{ Teamwork Cohesion } & $\begin{array}{l}\text { Pearson } \\
\text { Correlation }\end{array}$ & $.716^{* *}$ & 1 & -.113 & $.724^{* *}$ & $.670^{* *}$ \\
\hline & Sig. (2-tailed) & .000 & & .216 & .000 & .000 \\
\hline & $\mathrm{N}$ & 121 & 121 & 121 & 121 & 121 \\
\hline \multirow{3}{*}{ Group Potency } & \begin{tabular}{|l|} 
Pearson \\
Correlation \\
\end{tabular} & -.079 & -.113 & 1 & -.097 & -.032 \\
\hline & Sig. (2-tailed) & .391 & .216 & & .292 & .724 \\
\hline & $\mathrm{N}$ & 121 & 121 & 121 & 121 & 121 \\
\hline \multirow{3}{*}{$\begin{array}{l}\text { Persistent } \\
\text { Communication }\end{array}$} & $\begin{array}{l}\text { Pearson } \\
\text { Correlation }\end{array}$ & $.707^{* *}$ & $.724^{* *}$ & -.097 & 1 & $.619^{* *}$ \\
\hline & Sig. (2-tailed) & .000 & .000 & .292 & & .000 \\
\hline & $\mathrm{N}$ & 121 & 121 & 121 & 121 & 121 \\
\hline \multirow{3}{*}{ Incentives } & $\begin{array}{l}\text { Pearson } \\
\text { Correlation } \\
\end{array}$ & $.738^{* *}$ & $.670^{* *}$ & -.032 & $.619^{* *}$ & 1 \\
\hline & Sig. (2-tailed) & .000 & .000 & .724 & .000 & \\
\hline & $\mathrm{N}$ & 121 & 121 & 121 & 121 & 121 \\
\hline
\end{tabular}

Source: Writer's compilation (2020)

Table 5 shows the report of the correlation analysis carried in the study. It is important to have significant relationship to interpret correlation (Ugurlu, 2009). The result reveals that organizational performance and teamwork have positive relationship between each other, and it is bi-directional. Organizational performance and group potency have a negative relationship between each other, and it is bi-directional. Organizational performance and persistent communication reveal a positive association-ship between one another while Organizational performance and incentives also show positive relationship between each other during the study period. 


\subsection{Regression Analysis}

Table 6: Results of the Regression Model

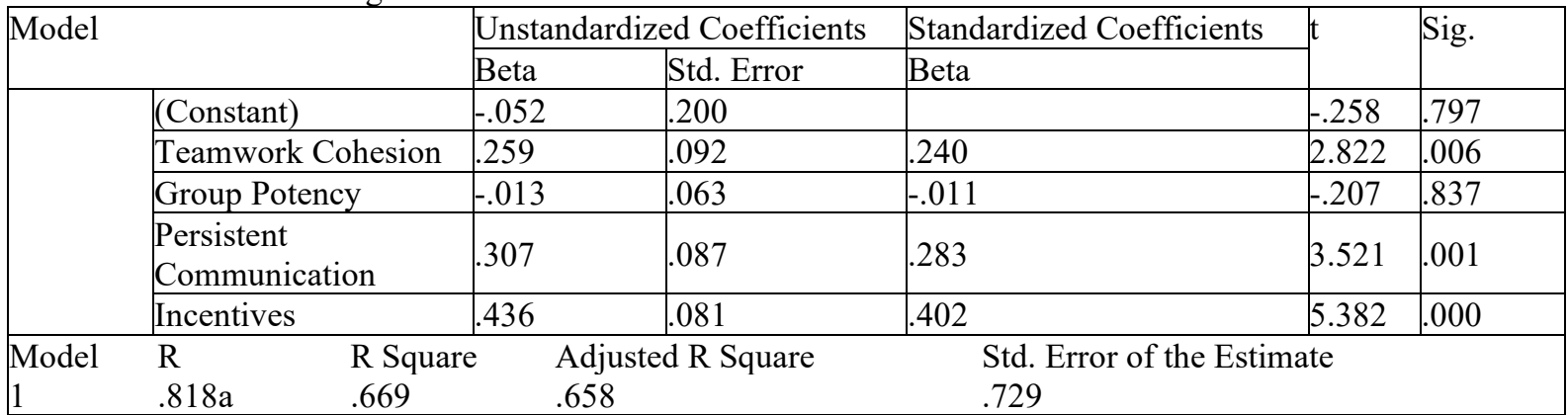

a. Predictors: (Constant), Incentives, Group Potency, Persistent Communication, Teamwork Cohesion

b. Dependent Variable: Organizational Performance

\section{Source: Writer's compilation (2020)}

The result in Table 6 shows that the R-squared is moderately good with the value of $0.669(66.9 \%)$ implying that the multiple coefficient of determination (R-squared) is above average that is all the coefficient of the independent variables have above $66 \%$ expectation ratio of the dependent variable.

The coefficient of the regression analysis revealed in Table 5 displays the independent variables coefficient contributions to the dependent variable. If the coefficient is significant it shows that there is a relation between the independent and dependent variable (Uğurlu 2009). The results show that teamwork cohesion coefficient value is 0.240 with significant value of 0.006 . This indicates that teamwork cohesion is positive and significant to impact on organizational performance which also implies that a unit increase in teamwork will lead to an increase in organizational performance with value of 0.240 . group potency coefficient value reveals -0.11 with significant value of 0.837 indicating that group potency is negative and not significant to impact on organizational performance during the survey. Persistent communication coefficient value is 0.283 with significant value of 0.001 meaning that persistent communication is positive and significant to impact on organizational performance. However, incentives coefficient value is 0.402 with significant value of 0.000 , indicating that incentives exhibits a positive and significant impact on organizational performance.

\section{Conclusion}

Teamwork in an organization setting has been opined by some researcher as a vital tool in efficient utilization of resources. Based on the rigorous investigation that this study carried out in relation to teamwork and organizational performance, some conclusions are made in line with the analysis and findings. It was concluded that the performance of organization is a subset of operating performance while teamwork is a subset of unit performance and teamwork cohesion gives employees a sense of possession and promotes cooperation. The study also concluded that teamwork cohesion stimulates group potency and improve decision making among employees. More so, the study equally concluded that organizational performance, teamwork, persistent communication, and incentives have positive relationship between one another which is bi-directional. Furthermore, teamwork cohesion exerts positive and significant impact on organizational performance, group potency revealed a negative and not significant impact on organizational performance, persistent communication exhibited a positive and significant impact on organizational performance while displayed a positive and significant impact on organizational performance.

Based on the findings and conclusion, this study recommended the following

i. The managers including the top management should persistently communicate to encourages teamwork cohesion thereby stimulates group potency and improve decision making among employees in their organization.

ii. The management should encourage not to neglect low and middle levels to focus on top-level management in organizational communication and teamwork cohesion.

iii. The management at all levels should improve on the incentives of the employees and this will in turn expands the collaboration and output of each employee either financial or non-financial incentive.

\section{References}

Adeleke, A. A. (2008). Appraising team management as a strategy to motivate change and business performance. Study of Tower Aluminum (Nig) Plc. Unpublished BSc thesis submitted to the Department of Business Administration, University of Ado-Ekiti, Nigeria.

Agarwal, S. \& Adjirackor, T. (2016). Impact of Teamwork on Organizational Productivity in Some Selected Basic 
Schools in The Accra Metropolitan Assembly, European Journal of Business, Economics and Accountancy, $4(6), 40-52 *$.

Agwu, M. O. (2015). Teamwork and Employee Performance in the bonny Nigeria Liquefied Natural Gas Plant*. American Research Institute for Policy Development, 3(4), 39-60.

Boakye, E. O. (2015). The impact of teamwork on employee performance. Researchgate · November 2015 DOI: 10.13140/RG.2.1.4959.8804

Brown, D. \& Don, H. (1996). An experimental approach to organization development. $5^{\text {th }}$ edition. USA: Prentice Hall.

Frobel, P. \& Marchington, M. (2005). Teamwork structures and worker perception: a cross- national study in Pharmaceuticals. International Journal of Human Resource Management. 16(2), 256-276.

Hartenian, L.S. (2003). Team member acquisition of team knowledge, skills, and abilities. Journal of Team Performance Management, 9(1/2), 23-30.

Howard, L. W., Turban, D. B., \& Hurley, S. K. (2016). Cooperating teams and competing reward strategies: Incentives for team performance and firm productivity. Journal of Behavioral and Applied Management, 3(3), $10-54$.

Khan, S. \& Al-Mashikhi, L. S. (2017). Impact of Teamwork on Employees Performance. International Journal of Education and Social Science, 4(11), 14-22.

Ooko, P. A. \& Odundo, P. (2015). Impact of Teamwork on the Achievement of Targets in Organisations in Kenya: A Case of SOS Children's Villages, Eldoret, European Journal of Business and Management 7(14), 69-77.

Salman, W. A. \& Hassan, Z. (2016). Impact of Effective Teamwork on Employee Performance. International Journal of Accounting \& Business Management, 4(1), 76-85.

Sanyal, S. \& Hisam, M. W. (2018). The Impact of Teamwork on Work Performance of Employees: A Study of Faculty Members in Dhofar University. DOI: 10.9790/487X-2003011522.

Steiner I. (1972). Group process and productivity. New York: Academy Press.

Uğurlu, E. (2009). Real Exchange Rate and Economic Growth: Turkey, Manas Üniversitesi Sosyal Bilimler Dergisi , 11 (22) , 191-212 . Retrieved from https://dergipark.org.tr/tr/pub/manassosyal/issue/49930/639816

Uğurlu F. S. (2019). Relationship between Bank credits and Regional growth: the case of Turkey. Journal of Science and Innovative Technologies, Baku, Azerbaijan, DOI: 10.5782/2616- 7.2019.81, Volume 7 Number $1,81-92$

Wanyeki, M. N., Maina, C. W., Sanyanda, J. N. \& Kiiru, D. (20019). Impact of Teamwork on Employee Performance: Study of Faculty Members in Kenyatta University. Journal of Human Resource and Leadership, $4(1), 1-8$ 